\title{
Effect of dietary mannan-oligosaccharides from copra meal on intestinal microbes and blood profile of broiler chickens
}

\author{
A.N.S. Putri ${ }^{1}$, Sumiati ${ }^{2}$ and A. Meryandini ${ }^{1}$ \\ ${ }^{1}$ Faculty of Mathematics and Natural Sciences, Bogor Agricultural University, \\ Jl. Agatis, Dramaga, Bogor 16680 - Indonesia \\ ${ }^{2}$ Faculty of Animal Science, Bogor Agriculture University, \\ Jl. Agatis, Dramaga, Bogor 16680 - Indonesia \\ CorrespondingE-mail : ameryandini@yahoo.com \\ Received December 23, 2016; Accepted March 02, 2017
}

\begin{abstract}
ABSTRAK
Mannan-oligosakarida (MOS) merupakan salah satu prebiotik yang digunakan sebagai komponen pangan fungsional dalam pakan. Penggunaan MOS dapat dijadikan alternatif antibiotik untuk menurunkan jumlah bakteri patogen. Penelitian ini bertujuan menganalisis pengaruh pemberian MOS asal bungkil kopra terhadap mikroba usus dan profil darah ayam pedaging. Penelitian dilakukan menggunakan 150 ekor day old broiler chickens jantan (rerata bobot badan awal 46,00 $\pm 1,41 \mathrm{~g}$ ). Rancangan yang digunakan dalam penelitian ini adalah Rancangan Acak Lengkap dengan 3 perlakuan, 5 ulangan, dan 10 ekor ayam per ulangan. Perlakuan pakan yang digunakan adalah: kontrol (pakan berbasis jagung-bungkil kedelai yang tidak ditambahkan antibiotik dan prebiotik), kontrol $+0,1 \%$ antibiotik bambermisin, dan kontrol $+0,035 \%$ MOS asal bungkil kopra. Perlakuan pakan dilakukan selama 4 minggu, kemudian untuk 2 minggu setelahnya pakan yang diberikan adalah pakan komersial. Peubah yang diamati adalah populasi mikroba usus dan profil darah. Hasil penelitian menunjukkan bahwa penambahan $0,035 \%$ MOS meningkatkan jumlah bakteri asam laktat (BAL) secara signifikan dibandingkan pakan antibiotik $(\mathrm{P}<0,05)$, namun tidak berbeda nyata $(\mathrm{P}>0,05)$ dengan pakan kontrol. Jumlah total bakteri aerob dan coliform lebih tinggi pada perlakuan MOS dan antibiotik dibandingkan kontrol. Suplementasi $0,035 \%$ MOS asal bungkil kopra pada pakan meningkatkan jumlah leukosit yang berfungsi dalam sistem imun dan penggunaannya tergolong aman karena sebagian besar profil darah berada dalam kisaran normal.
\end{abstract}

Kata Kunci: BAL, Escherichia coli, mananase, prebiotik, Streptomyces sp. BF 3.1.

\begin{abstract}
Mannan-oligosaccharides (MOS) is a common prebiotics used as a feed additives. The use of antibiotic can be replaced by MOS to reduce the number of pathogenic bacteria in small intestines of chickens. The objective of this study was to determine the effect of MOS extracted from copra meal on intestinal microbial population and blood profile of broiler chickens. The study was conducted by using 150 day-old male broiler chickens (average body weight $46.00 \pm 1.41 \mathrm{~g}$ ). The design of this experiment was a completely randomized design (CRD) with 3 dietary treatments, 5 replications and 10 birds in each replication. The dietary treatments consisted of control diet (corn-soybean meal diet without supplementation of antibiotic and prebiotic), control $+0.1 \%$ antibiotic bambermycin, and control + $0.035 \%$ MOS. For the first 4 weeks the birds were fed treatment diets, followed by commercial feed for 2 weeks. The parameters observed in this study were intestinal microbes population and blood profiles. The results showed that the administration of $0,035 \%$ MOS increased the lactic acid bacteria (LAB)
\end{abstract}


number compared with antibiotics feed $(\mathrm{P}<0.05)$, but not significantly different $(\mathrm{P}>0.05)$ with the control group. The total aerobic and coliform bacteria were higher in MOS and antibiotic treatment compared than control group. The supplementation of $0.035 \%$ MOS from copra meal in diet increased the level of leucocytes which is important to immune response of broilers and its usage was safe because the level of chicken blood profile were within the normal range.

Keywords : LAB, Escherichia coli, mannanase, prebiotic, Streptomyces sp. BF 3.1.

\section{INTRODUCTION}

Diseases caused by pathogens infection is one of the critical issues. Pathogenic bacteria proliferation in the intestine often reduce the productivity and cause contamination in poultry products. Antibiotics is widely used to inhibit the growth of pathogenic bacteria Escherichia coli in avian species. Antibiotics is widely used in feed as a growth promotor (Gaskins et al., 2002), however the continuous usage of antibiotics can lead to bacterial resistance especially E.coli (Hasan et al., 2011). The European Union has banned the use of antibiotics in feed. Consequently, the search for alternatives to antibiotics has become an important topic of research.

Prebiotic is defined as non-digestible food ingredients that can improve the host health by selectively stimulating one or a number of beneficial bacteria growth in the gut (Gibson and Roberfroid, 1995). Mannan-oligosaccharides (MOS) and some other types oligosaccharides are examples of prebiotics. Besides the activity to inhibit colonization of pathogens, MOS is also known for its immunomodulating effect (Hajati and Rezaei, 2010). The MOS has been shown to improve immune response of broiler chickens (Fernandez et al., 2002).

Commercial MOS used for poultry feed additive are obtained from the outer layer of yeast cell walls (Saccharomyces cerevisiae). Administration of $0.05 \%$ commercial MOS in poultry feed increased populations and diversity of lactobacilli, and reduced the population of $E$. coli in chicken intestines (Kim et al., 2011). Besides the extraction from yeast cell walls, MOS can also be produced from enzymatic hydrolysis of agricultural waste such as copra meal (Ariandi et al., 2015).

Copra meal is a by-product of coconut oil extraction process which is available abundantly and cheap. Copra meal contains $70 \%$ of total carbohydrate most of which $(80 \%)$ consists of mannan polysaccharides (Khuwijitjaru et al., 2012), subsequently, copra meal can be hydrolyzed using mannanase to produce MOS. The use of copra meal as materials for MOS is expected to increase the usefulness of this agricultural waste.

Some actinomycetes namely Streptomyces sp. BF 3.1 (Ariandi et al., 2015) have been reported to produce mannanase that are capable to hydrolyze copra meal into MOS. The objective of this study was to determine the effect of MOS produced enzymatically from copra meal on the intestinal microbial population and blood profiles in broiler chickens.

\section{MATERIALS AND METHODS}

\section{Production and Analysis of Mannan- oligosaccharides}

The MOS was produced from enzymatic hydrolysis of copra meal by mannanase produced from Streptomyces sp. BF 3.1 (Ariandi et al., 2015). The production of mannanase and MOS was conducted according to crude enzyme production by Ariandi et al. (2015) with several modifications. Fermentation was performed for 10 days, at about $27^{\circ} \mathrm{C}$. The MOS extract was obtained as the culture supernatant by centrifugation $\left(3000 \mathrm{~g}, 15 \mathrm{~min}, 4^{\circ} \mathrm{C}\right)$. The supernatant then evaporated using rotary pan evaporator at $50^{\circ} \mathrm{C}, 50 \mathrm{mmHg}$. The MOS products were analyzed by high performance liquid chromatography (HPLC) agilent 1260 infinity using glucose, galactose, mannose, mannobiose, mannotriose, mannotetraose, and mannopentose as standard. MOS products were analyzed by HPLC under the following conditions: column Hi-Plex Ca (Duo), eluent milli-Q HPLC grade, column temperature $85^{\circ} \mathrm{C}$, a flow rate of $0.6 \mathrm{~mL} / \mathrm{min}$ and a refractive index detector monitor (RID).

\section{Experimental Design}

The study was conducted by using 150 dayold male broiler chickens (Lohmann) having the initial body weight of $46.00 \pm 1.41 \mathrm{~g}$. The design used in this experiment was a completely randomized design (CRD) with 3 dietary 
treatments, 5 replications and 10 chickens in each replication. The dietary treatments consisted of control diet (corn-soybean meal diet without supplementation of antibiotic and prebiotic) (Table 1 ), control $+0.1 \%$ antibiotic bambermycin, and control $+0.035 \%$ MOS (extracted from copra meal). The birds were given the dietary treatments for 4 weeks, followed by commercial feed for 2 weeks. The feed formulation was according to the nutrient requirements based on Leeson and Summers (2005). The variables measured were intestinal microbial population, and blood profiles.

\section{Intestinal Microbes Analysis}

The intestinal microbial population was determined at 28 days and at 42 days of age. One bird was randomly selected from each replicate and slaughtered to collect the intestinal contents samples for microbial counts. The gastrointestinal tract was removed from the carcasses, ileal content was obtained from $10-\mathrm{cm}$ segments of the upper part of the ileocecal junction. The calculation of intestinal microbes was done using

Table 1. Composition and Nutrient Content of Experimental Diet of 1-4 Weeks-old Broilers

\begin{tabular}{|c|c|c|c|}
\hline \multirow{2}{*}{ Feed Ingredients (\%) } & \multicolumn{3}{|c|}{ Feed } \\
\hline & control & $0.1 \%$ antibiotic & $0.035 \% \mathrm{MOS}$ \\
\hline Corn & 59 & 59 & 59 \\
\hline Rice bran & 3 & 2.9 & 2.965 \\
\hline Corn Gluten Meal & 5.5 & 5.5 & 5.5 \\
\hline Soybean meal & 21.70 & 21.70 & 21.70 \\
\hline Fish meal & 8 & 8 & 8 \\
\hline Palm oil & 1.5 & 1.5 & 1.5 \\
\hline $\mathrm{CaCO}_{3}$ & 1 & 1 & 1 \\
\hline $\mathrm{NaCl}$ & 0.2 & 0.2 & 0.2 \\
\hline DL-metionin & 0.1 & 0.1 & 0.1 \\
\hline Bambermycin antibiotic & 0 & 0.1 & 0 \\
\hline MOS from copra meal & 0 & 0 & 0.035 \\
\hline Total & 100 & 100 & 100 \\
\hline \multicolumn{4}{|c|}{ Nutrient content (calculated value / \%)*: } \\
\hline Metabolizable energy $(\mathrm{kcal} / \mathrm{kg})$ & 3,091 & 3,089 & 3,090 \\
\hline Protein & 22.25 & 22.24 & 22.25 \\
\hline Extract ether & 2.80 & 2.79 & 2.80 \\
\hline Crude fiber & 2.70 & 2.69 & 2.70 \\
\hline Lysine & 1.30 & 1.30 & 1.30 \\
\hline Methionine & 0.62 & 0.62 & 0.62 \\
\hline Cystine & 0.38 & 0.38 & 0.38 \\
\hline Methionine + cystine & 0.99 & 0.99 & 0.99 \\
\hline Linoleic acid & 1.90 & 1.90 & 1.90 \\
\hline Calcium & 0.96 & 0.96 & 0.96 \\
\hline Phosphor & 0.50 & 0.50 & 0.50 \\
\hline Sodium & 0.16 & 0.16 & 0.16 \\
\hline Chloride & 0.21 & 0.21 & 0.21 \\
\hline
\end{tabular}

Nutrient content calculated based on Leeson and Summers (2005). 
Total Plate Count (TPC) method. Groups of bacteria were cultured and then were calculated for the total aerobic bacteria, lactic acid bacteria (LAB) and coliform. Total aerobic bacteria was cultured using Nutrient Agar (NA) medium, LAB using Man Rogosa Sharpe-Agar (MRSA) medium, while coliform using Salmonella Shigella Agar (SSA) medium.

A total of $1 \mathrm{~g}$ ileal content was placed into a test tube contained $9 \mathrm{~mL}$ of $0.85 \%$ physiological saline, then rapidly homogenized using a vortex. The solution then serially diluted using physiological saline from $10^{-1}$ to $10^{-5}$ dilution. A total of $100 \mu \mathrm{L}$ sample solution of $10^{-3}, 10^{-4}$, and $10^{-5}$ dilution respectively were distributed into Petri dishes containing NA, MRSA, and SSA media using spread method. The analysis was performed duplo. The total aerobic bacteria in NA medium and LAB in MRSA medium were incubated at $37^{\circ} \mathrm{C}$ for 48 hours, however coliform in SSA medium were incubated at $37^{\circ} \mathrm{C}$ for 24 hours. Coliform in SSA medium shown as pink colony.

\section{Blood Profile Analysis}

Blood Profiles of the experimental bird determined were erythrocytes, hemoglobin, hematocrit, leukocyte and leukocyte differentiation. At 28 days of age, one bird was randomly sampled from each replicate and blood samples were taken from the wing brachial vein. Blood profile analysis was conducted following the procedures described by Harvey (2012).

\section{Statistical Analysis}

Analysis of variance (ANOVA) was used to analyze data by using a GLM procedure (SPSS V23). Significant differences among treatment means were tested using Duncan's multiple range test with $\mathrm{P}<0.05$.

\section{RESULTS AND DISCUSSIONS}

\section{Product Analysis using High Performance Liquid Chromatography}

Total MOS obtained from the production process were $21.745 \mathrm{~g}$, so it is equivalent to $0.035 \%$ of MOS. Kim et al. (2011) showed that low concentration of MOS $(0.025 \%$ and $0.05 \%)$ yielded greater body weight gains of broiler chickens than BW gains of broiler chickens in control group and increased levels of lactobacilli compared to avilamycin and control group. Copra meal hydrolysis products were detected by high performance liquid chromatography (Figure 1). The results of copra meal hydrolysis using HPLC showed three peaks (Figure 1). MOS products namely mannopentose and mannobiose detected in the first and second peak with a retention time of 6.5 minutes and 9.5 minutes respectively. Mannose monomer detected in the third peak with a retention time of 11 minutes. Mannopentose dominated the hydrolysis products with a concentration of $159.545 \mathrm{~g} / \mathrm{L}$, while mannobiose concentrations were detected in $0.909 \mathrm{~g} / \mathrm{L}$. Mannose concentration detected quite low at $0.445 \mathrm{~g} / \mathrm{L}$.

The products in this study were similar to the results of copra meal hydrolysis by mannanase Streptomyces sp. BF 3.1 in previous study (Ariandi et al., 2015). Mannopentose and mannobiose which yielded in this study due to the activity of $\beta$-mannanase. $\beta$-mannanase is endotype enzyme which responsible to hydrolize $\beta$ 1,4-linked of the mannan backbone randomly to produce new chain ends. The presence of mannose in the hydrolysis product due to the $\beta$ mannosidase. $\beta$-mannosidase is exo-type enzyme which responsible to hydrolize $\beta$-1,4-linked mannosides to release mannose from the nonreducing end of mannans and mannooligosaccharides (Moreira and Filho, 2008).

\section{Effect of Dietary MOS on Intestinal Microbial Populations}

The mean of total aerobic bacteria, $\mathrm{LAB}$, and coliform in 4 weeks old broiler chicken intestines are presented in Table 2. Total aerobic bacteria in chickens fed diets with MOS and that containing antibiotic were significantly higher $(\mathrm{P}<0.05)$ than those fed the control diets.

Mannan-oligosaccharides (MOS) is an example of prebiotic. As prebiotic, MOS suggested to selectively stimulating one or a number of beneficial bacteria growth in the gut. The higher total aerobic bacteria in birds fed MOS-supplemented diets could be due to of the presence of oligosaccharides and simple sugars in the MOS which could be utilized by all bacteria as a carbon source for growth. In the other words, simple sugars contained in hydrolysate provided a substrate for all gastrointestinal bacteria. MOS and other prebiotics could selectively stimulating beneficial bacteria because of the oligosaccharides structure. Oligosaccharides can not utilized by pathogens, otherwise simple sugar.

This result is in line with that of Kim et al. 


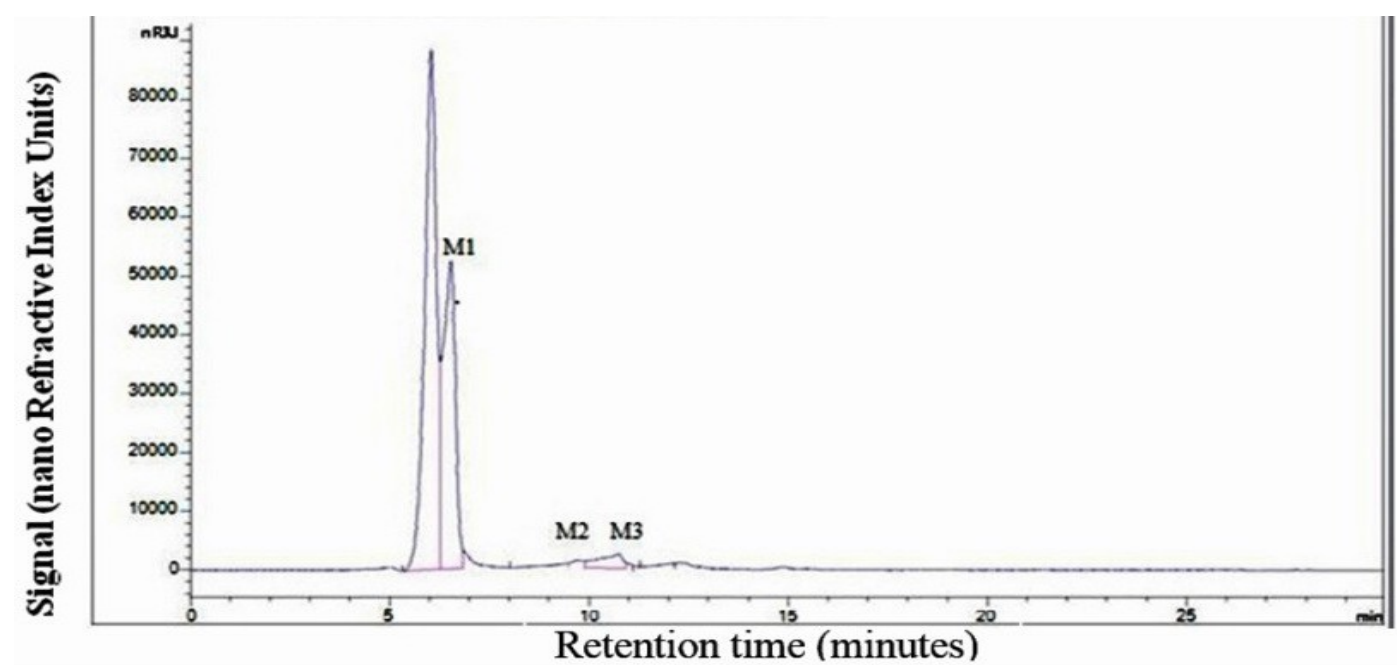

Figure 1. Results of the Analysis of Copra Meal Hydrolysis using High Performance Liquid Chromatography. Chromatographic conditions: column Hi-Plex Ca (Duo), eluent milli-Q HPLC grade, column temperature $85^{\circ} \mathrm{C}$, a flow rate of $0.6 \mathrm{~mL} / \mathrm{min}$ and a refractive index detector monitor (RID). Hydrolysis products: manopentose (M1), manobiose (M2), manose (M3).

Table 2. Mean of Total Aerobic Bacteria, Lactic Acid Bacteria (LAB) and Coliform in 28 Days-old Broiler Chicken Intestines on Various Treatments

\begin{tabular}{lcccc}
\hline \multirow{2}{*}{ Variables } & \multicolumn{3}{c}{ Treatments } & \multirow{2}{*}{ Other studies } \\
\cline { 2 - 4 } & Control & $0.1 \%$ antibiotic & $0.035 \% \mathrm{MOS}$ & \\
\hline $\begin{array}{l}\text { Total aerobic bacteria } \\
\left(\mathrm{x} 10^{6} \mathrm{cfu} / \mathrm{g}\right)\end{array}$ & $0.32 \pm 0.14^{\mathrm{b}}$ & $4.31 \pm 1.58^{\mathrm{a}}$ & $4.10 \pm 1.41^{\mathrm{a}}$ & $10^{7 * * *}$ \\
LAB $\left(\times 10^{6} \mathrm{cfu} / \mathrm{g}\right)$ & $288.60 \pm 78.20^{\mathrm{a}}$ & $66.40 \pm 13.50^{\mathrm{b}}$ & $259.80 \pm 143^{\mathrm{a}}$ & $12.8 \times 10^{6}-302 \times 10^{6 * *}$ \\
Coliform $\left(\times 10^{6} \mathrm{cfu} / \mathrm{g}\right)$ & $0.28 \pm 0.08^{\mathrm{b}}$ & $4.33 \pm 1.53^{\mathrm{a}}$ & $3.64 \pm 1.71^{\mathrm{a}}$ & $1.58 \times 10^{6}-5.01 \times 10^{6 *}$ \\
LAB:Coliform & $1,000: 1$ & $15: 1$ & $71: 1$ & - \\
\hline
\end{tabular}

Means in the same row with different superscript indicates differ significantly $(\mathrm{P}<0.05)$. ${ }^{*}$ Based on Bjerrum et al. (2006), ${ }^{* *}$ Based on Chee et al. (2010), ***Based on Jin et al. (1998).

(2011) who showed that the total aerobic bacteria increased when $0.05 \%$ MOS from yeast cell wall was added to the feed. The higher number of total aerobic bacteria in the antibiotic treatment compared to the control diet may be caused by antibiotic resistant bacteria. Hasan et al. (2011) reported that more than $55 \%$ avian pathogenic E.coli resisted to at least one or more antibiotics and $36 \%$ isolates E.coli from broilers in Bangladesh showed multiple drug resistence phenotypes.

LAB in broilers with MOS supplemented feed was significantly higher than in broilers with antibiotic suplemented feed $(\mathrm{P}<0.05)$, but it was not significantly different from control feed $(\mathrm{P}>0.05)$. This result indicated that the administration of MOS and control feed for broiler increased the number of beneficial intestinal microbes compared with antibiotic feed. Total LAB in MOS treatment was not 
significantly different from the control feed due to the control feed containing a large number of nondigestible carbohydrates from various foodstuffs such as corn and soybean meal, which serves as a prebiotic. Corn-soybean meal diet was used in this study (Table 1). This diet was less sensitive to detect the effects of oligosaccharides on microbial populations, due to its oligosaccharides content. Soybean meal contains about 6\% raffinose and stachyose (Coon et al., 1990). Raffinose known as a non-digestible oligosaccharides.

Biggs et al. (2007) reported that the addition of $4 \mathrm{~g} / \mathrm{Kg}$ oligosaccharides (including MOS) to corn-soybean meal diets had no significant effect on the populations of cecal Bifidobacterium, Lactobacillius, Clostridium perfringens, or E.coli in 21-d-old chicks. While supplementation of 4 $\mathrm{g} / \mathrm{Kg}$ MOS into a dextrose-isolated soy protein diet that contained little or no indigestible oligosaccharides reduced cecal populations of $C$. perfringens (Biggs et al., 2007). This finding suggests that corn-soybean meal diet may be less sensitive than dextrose-isolated soy protein diet to detect the effects of oligosaccharides on microbial populations. However, the effects of MOS on cecal microbes were limited, with only a difference in the level of $C$. perfringens and not for the level of Bifidobacterium, Lactobacillius, or E.coli, even in the absence of soybean meal (Biggs et al., 2007).

The effects of MOS towards beneficial bacteria in the intestine of broilers are inconsistent. Kim et al. (2011) and Chee et al. (2010) reported that the amount of lactobacilli and $\mathrm{LAB}$ in the ileum of broilers supplemented with MOS (from yeast cell walls) were significantly higher $(\mathrm{P}<0.05)$ than those of broilers control or antibiotics supplemented diet. On the other hand, some studies reported that commercial MOS did not affect the population of lactobacilli (Spring et al., 2000; Biggs et al., 2007) and bifidobacteria in the cecum of broilers.

The amount of LAB was comparatively higher than total aerobic bacteria. This result indicated that $\mathrm{LAB}$ was not able to grow in the medium used to cultivate total aerobic bacteria (NA medium). LAB was not able to grow on the NA medium due to ecological dan physiological factors. $\mathrm{LAB}$ requires habitats with a low $\mathrm{pH}$ because it is acidophilic. The optimum $\mathrm{pH}$ for LAB growth are around 4.5-6.2. MRSA as LAB growth medium has a compatible $\mathrm{pH}$ with $\mathrm{LAB}$ optimum growth $\mathrm{pH}$ (around 5.5-5.9), while NA medium with $\mathrm{pH} 7$ is too alkaline for $\mathrm{LAB}$ growth. Besides that, $\mathrm{LAB}$ are able to grow in MRSA medium because it contains high amount of sugar $(20 \mathrm{~g} / \mathrm{L})$. A high sugar level allows LAB to perform fermentation process.

Total coliform bacteria was significantly lower in the intestines of birds fed control diet compared to MOS and antibiotics diets. The low level of coliform bacteria in the control group may be due to the non-digestible oligosaccharides contained in the corn-soybean diet. MOS extracted from copra meal did not reduce the population of coliform bacteria. This was suspected because of the mannose content in the MOS. Monosaccharides are not only be utilized by $\mathrm{LAB}$, but also can be utilized by other microbes as a carbon source (Maczulak et al., 1993). In the other words, specific fermentation process in the gut did not occur.

Moreover, the absence of MOS effect to reduce the population of coliform bacteria may also be caused by E.coli indigenous in broiler intestines that did not have type-1 fimbriae. Hajati and Rezaei (2010) suggested two theories about mechanism of manose to inhibit the growth of pathogenic bacteria. The first theory was MOS may adsorb bacteria containing type-1 fimbriae and inhibiting them to attach to the mucosal surface of the gut wall. The second theory was agglutination caused by MOS. MOS causes pathogenic cells with Type-1 fimbriae to aggregate, and then bringing them out of solution. E.coli that did not have Type-1 fimbriae were resistant to mannaose (mannose resistant strain) (Dozois et al., 1995). MOS can not adsorb bacteria that do not have Type-1 fimbriae, so they can attach to the mucosal surface of the gut wall. Not all of E.coli strains have Type-1 fimbriae. Mirelmann et al. (1980) reported that about half of the tested strains of E. coli expressed Type-1 fimbriae.

The effect of MOS towards coliform bacteria in the intestine of broilers are inconsistent. Several study reported that either MOS from yeast cell walls (Kim et al., 2011) or MOS from palm cernel (Fernandez et al., 2002) reduced the population of E.coli significantly compared with control feed. In agreement with our results, in a comparative study, Chee et al. (2010) and Biggs et al. (2007) reported that supplementation of MOS in diet did not reduce the population of E.coli in the intestine of broilers, while Konca et al. (2009) reported that supplementation of MOS in diet did not reduce the population of E.coli in 
the intestine of turkey.

In general, bacterial population showed that the amount of total aerobic bacteria, LAB and coliform in MOS-supplemented feed were higher compared to the control and antibioticsupplemented diets. The intestinal bacteria population in chicken fed with MOS feed were dominated by LAB with a ratio of 71: 1 . This result indicated that supplementation of MOS functioned as a prebiotic because it was able to modify the intestinal bacteria composition which was dominated by favorable LAB.

Lactic Acid Bacteria (LAB) is also known as beneficial bacteria in the gut. Microbes belonging to LAB expecially the genus of Lactobacillus and Bifidobacterium have been used as probiotic strains. The beneficial effects of LAB as probiotics in poultry were included: modify intestinal microbiota, stimulate immune system, reduce inflammatory reactions, prevent pathogen colonization, enhance animal performance, decrease carcass contamination, and decrease ammonia and urea excretion (Patterson and Burkholder, 2003).

However the number of coliform in birds fed MOS-supplemented diet was higher than the control. However, not all of coliform bacteria (Escherichia coli) are pathogenic. E. coli is a normal inhabitant of human and other mammals' gastrointestinal tract (Kaper et al., 2004). Avian pathogenic E. coli (APEC) contained in chicken intestines are pathogenic because they have fimbriae type 1 as virulence factors (Dozois et al., 1994), however not all of E. coli in chicken intestines have the virulence factors. E.coli has some benefits for the host digestion, for example it produces vitamin K (Ramotar et al., 1984).
Birds fed antibiotic-supplemented diets showed a decrease in $\mathrm{LAB}$ population. This result suggested that antibiotic bambermycin was effective to kill LAB which is a group of Grampositive bacteria, meanwhile Gram-negative bacteria like coliform were resistant to this antibiotic. These results were consistent with the findings of van den Bogaard et al. (2001) who reported that most of antibiotic growth promotor only killed Gram-positive bacteria, while the group of Gram-negative bacteria such as E. coli were resistant. Ionophores antibiotic including bambermycin had no effect on the in vitro foodborne pathogens caused by Salmonella and E.coli O157:H7 (Edrington et al., 2003). The decrease of LAB level and the resistence of coliform caused by coliform and other bacteria growth rapidly due to the increase of carbon availability. That's why total aerobic bacteria and coliform bacteria in birds fed antibioticsupplemented diets were higher than control feed.

The population of bacteria was also calculated at 42 days of age to analyze the changes of microbial population after the chickens were untreated with MOS, antibiotic, and control feed. The comparison of total aerobic bacteria and LAB in broiler chickens (ileum segment) after fed with treatment diet ( 28 days old), and followed by fed with commercial diet (42 days old) are presented in Table 3.

MOS administration during 28 days old was triggered LAB growth. Replacement of control, antibiotic, and MOS feed into commercial feed during 29-42 days old of broilers reduced LAB number and increased the amount of total aerobic bacteria. This result indicated that the commercial feed (containing better nutrients) made aerobic

Table 3. Comparison of Total Aerobic Bacteria and LAB in 4 Weeks and 6 Weeks Old Chickens

\begin{tabular}{lcccccc}
\hline \multirow{2}{*}{\multicolumn{1}{c}{ Variables }} & \multicolumn{5}{c}{ Treatments } \\
\cline { 2 - 7 } & \multicolumn{5}{c}{ Control } & \multicolumn{5}{c}{$0.1 \%$ antibiotic } & $0.035 \%$ MOS \\
\cline { 2 - 7 } & \multicolumn{5}{c}{ Age (days) } \\
\cline { 2 - 7 } & 28 & 42 & 28 & 42 & 28 & 42 \\
\hline Total aerobic bacteria $\left(\times 10^{6} \mathrm{cfu} / \mathrm{g}\right)$ & 0.32 & 0.67 & 4.31 & 4.87 & 4.10 & 5.14 \\
$\mathrm{SD}$ & 0.14 & 0.28 & 1.58 & 0.81 & 1.41 & 2.70 \\
$\mathrm{LAB}\left(\mathrm{x} 10^{8} \mathrm{cfu} / \mathrm{g}\right)$ & 2.89 & 0.12 & 0.66 & 0.41 & 2.60 & 0.14 \\
$\mathrm{SD}$ & 0.78 & 0.05 & 0.13 & 0.34 & 1.43 & 0.02 \\
\hline
\end{tabular}


bacteria besides LAB grew rapidly.

Compositional changes of the intestinal microbiota that occurred during the 2 weeks after the unadministration of MOS (29-42 days old) did not change the performance of broilers significantly (data not shown). Commercial broilers are usually slaughtered at 5 to 7 weeks of age, thereby the administration of MOS for 4 weeks was enough to maintain the health of broilers before slaughtered.

\section{The effect of dietary MOS administration on blood profile}

The health status and immune response of broilers chickens reflected through the blood profile. The effect of MOS administration on 28 days old broiler chickens blood profile are presented in Table 4. In general, the treated MOS broiler chickens blood profiles were not significantly different from other treatments, however the administration of $0.035 \%$ MOS increased the number of leukocytes $(\mathrm{P}<0,05)$.

The number of leukocytes in this study was lower compared to a standard leukocyte count in broilers. This lower number of leukocyte may due to the heat stress during sampling process. Tamzil et al. (2014) reported that the heat stress condition in chickens can reduce leukocytes number up to $40 \%$. The number of leukocytes which present in broilers fed feed containing MOS was significantly higher than other treatments $(\mathrm{P}<0.05)$. Leukocytes are immune cells that response to incoming antigen, so this result indicated that the administration of $0.035 \%$ MOS from copra meal improved blood constituent which were important to immune response of broilers. This result was in line with Fernandez et al. (2002) study which stated that the supplementation of palm kernel cake (containing mannan) to diet can improve immune response of broilers. Other research reported that the addition of prebiotic MOS from yeast cell walls to the feed had a positive influence on some biochemical indices of blood (including $\gamma$ globulin) which were important to immune response of broilers. (Sirvydis et al., 2006). On the other hand, several study reported that commercial MOS did not affect neither the blood constituents of turkey (Konca et al., 2009) nor immune response of broilers (Kim et al., 2011). MOS had been reported to have immunomodulation effect.

$\beta$-glucan oligosaccharides (such as MOS from yeast cell walls) have immunomodulation effect by enhancing phagocytosis and proliferation of monocytes and macrophages (Novak and Vetvicka, 2008). Increased production of macrophages causes the host immune system increases. Beneficial effects of prebiotics on

Table 4. Blood Profiles of 28 Days old Broiler Chickens in Various Treatments

\begin{tabular}{lcccc}
\hline \multirow{2}{*}{\multicolumn{1}{c}{ Variables }} & \multicolumn{3}{c}{ Treatments } & Standard \\
\cline { 2 - 4 } & Control & $0.1 \%$ Antibiotic & $0.035 \% \mathrm{MOS}$ & \\
\hline Erythrocytes $\left(\mathrm{x} 10^{6} \mathrm{~mm}^{-3}\right)$ & $3.37 \pm 0.59$ & $3.21 \pm 0.34$ & $3.41 \pm 0.39$ & $2.5-3.5^{*}$ \\
Hemoglobin $(\mathrm{g} \%)$ & $7.78 \pm 1.50$ & $7.83 \pm 0.45$ & $8.21 \pm 0.73$ & $7-13^{*}$ \\
Hematocrit (\%) & $24.21 \pm 4.47$ & $25.69 \pm 1.85$ & $26.56 \pm 2.22$ & $23-35^{* *}$ \\
Leukocytes (x10 $\left.\mathrm{mm}^{-3}\right)$ & $7.57 \pm 2.01^{\mathrm{a}}$ & $7.30 \pm 1.39^{\mathrm{a}}$ & $11.13 \pm 1.05^{\mathrm{b}}$ & $12-30^{*}$ \\
Heterophil (\%) & $8.83 \pm 1.61$ & $11.33 \pm 1.26$ & $15.83 \pm 7.28$ & $15-50^{* *}$ \\
Lymphocytes (\%) & $89.17 \pm 1.61$ & $87.5 \pm 1.00$ & $82.17 \pm 6.81$ & $29-84^{* *}$ \\
Monocytes (\%) & $2.00 \pm 0.58$ & $1.25 \pm 0.29$ & $2.00 \pm 0.41$ & $0-7^{* *}$ \\
Eusinophil (\%) & $0.00 \pm 0.00$ & $0.00 \pm 0.00$ & $0.00 \pm 0.00$ & $0-16^{* *}$ \\
Basophil (\%) & $0.00 \pm 0.00$ & $0.00 \pm 0.00$ & $0.00 \pm 0.00$ & $0-8^{* *}$ \\
H/L Ratio & $0.10 \pm 0.02$ & $0.13 \pm 0.01$ & $0.19 \pm 0.08$ & $<1$ \\
\hline
\end{tabular}

Means in the same row with different superscript differ significantly $(\mathrm{P}<0.05) .{ }^{*}$ Based on Zinkl (1986), ***Based on Pollack et al. (2005) 
different immune functions, such as the production of cytokines and mucosal immunoglobulin, an increase in serum, an increase in the number of Peyer's patches, and mesentric lymph node, an increase on macrophage phagocytosis, and also altered leucocyte and lymphocyte numbers have been reviewed (Schley and Field, 2002).

Baurhoo et al. (2007) suggested that the beneficial effects of most additives (including MOS) were obviously under stressfull or in suboptimal conditions, such as a disease condition, a high stocking density, and bad management practices. Stressors have negative effects on the intestinal microbes balance (Lan et al., 2004). Prebiotics were able to promote the positive effects on the intestinal microbes, so dietary supplementation of prebiotics can modulate the physiological stress response and consequently enhance tolerance to stress (Ghareeb et al., 2008). Sohail et al. (2010) reported that dietary supplementation with prebiotics reduced some negative effects of heat stress in broilers. In contrast, Houshmand et al. (2012) reported that supplementation with MOS prebiotic had no significant effect on stress indicator.

The number of heterophiles and lymphocytes in MOS treatment were within the normal range, while in antibiotic and control treatment the number of heterophiles were below the standard and the number of lymphocytes were above the standard. These results indicated that the supplementation of MOS from copra meal could against incoming antigen. The low number of heterophils in antibiotic and control treatment may be cause of virus infection. Infection of infectious bursal disease virus (IBDV) caused macrophage to undergo apoptosis (Lam, 1998). The usage of $0.035 \%$ MOS in feed was safe as shown by the level of several blood profiles of broilers which was within the normal range.

\section{CONCLUSION}

The addition of $0.035 \%$ MOS extracted from copra meal in broiler diets increased the $\mathrm{LAB}$ populations in the ileum compared to diets supplemented with antibiotics feed, but it was not significantly different with the control group. The total aerobic bacteria and coliform bacteria were higher in MOS and antibiotic treatment compared than control group. The supplementation of $0.035 \%$ MOS from copra meal in diet increased the level of leucocytes which is important to immune response of broilers and its usage was safe because the levels of some chicken blood profile were within the normal range.

\section{ACKNOWLEDGMENTS}

This study was financially supported by research grant provided by Directorate Research and Community Service, Directorate General of Higher Education Republic of Indonesia, Ministry of Research, Technology and Higher Education for Anja Meryandini.

\section{REFERENCES}

Ariandi, Yopi, and A. Meryandini. 2015. Enzymatic hydrolysis of copra meal by mannanase from Streptomyces sp. BF 3.1 for the production of mannooligosaccharides. Hayati. J. Biosci. 22: 79-86.

Baurhoo, B., L. Philip, and C.A. Ruiz-Feria. 2007. Effects of purified lignin and mannan oligosaccharides on intestinal integrity and microbial populations in the ceca and litter of broiler chickens. Poult. Sci. 86:10701078.

Biggs, P., C.M. Parsons, and G.C. Fahey. 2007. The effects of several oligosaccharides on growth performance, nutrient digestibilities, and cecal microbial populations in young chicks. Poult. Sci. 86:2327-2336.

Bjerrum, L., R.M. Engberg, T.D. Leser, B.B. Jensen, K. Finster, and K. Pedersen. 2006. Microbial community composition of the ileum and cecum of broiler chickens as revealed by molecular and culture-based techniques. Poult. Sci. 85: 1151-1164.

Chee, S.H., P.A. Iji, M. Choct, L.L Mikkelsen, and A. Kocher. 2010. Characterisation and response of intestinal microflora and mucins to manno-oligosaccharide and antibiotic supplementation in broiler chickens. British. Poult. Sci. 51:368-380.

Coon, C.N., K.L. Leske, O. Akavanichan, and T.K. Cheng. 1990. Effect of oligosaccharide-free soybean meal on true metabolizable energy and fiber digestion in adult roosters. Poult. Sci. 69:787-793.

Dozois, C.M., N. Chanteloup, M. Dho-Moulin, A. Bree, C. Desautels, and J.M. Fairbrother. 1994. Bacterial colonization and in vivo expression of FI (type I ) fimbrial antigens in chickens experimentally infected with 
pathogenic Escherichia coli. Avian Dis. 38: 231-239.

Dozois, C.M., S.A. Pourbakhsh, and J.M. Fairbrother. 1995. Expression of P and type 1 (F1) fimbriae in pathogenic Escherichia coli from poultry. Vet. Microbiol. 45: $297-$ 309.

Edrington, T.S., T.R. Callaway, P.D. Varey, Y.S. Jung, K.M. Blschoff, R.O. Elder, R.C. Anderson, E. Kutter, A.D. Brabban, and D.J. Nisbet. 2003. Effects of the antibiotic ionophores monesin, lasalocid, iaidlomycin propionate and bambermycin on Salmonella and E.coli O157:H7 in vitro. J. Appl. Microbiol. 94: 207-213.

Fernandez, F., M. Hinton, and B.V. Gils. 2002. Dietary mannan-oligosaccharides and their effect on chicken caecal microflora in relation to Salmonella Enteritidis colonization. Avian. Pathol. 31: 49-58.

Gaskins, H.R., C.T. Collier, and D.B. Anderson. 2002. Antibiotics as growth promotants: Mode of action. Anim. Biotechnol. 13: 2942.

Ghareeb, K., W.A. Awad, S. Nitsch, S. AbdelRaheem, and J. Bohm. 2008. Effects of transportation on stress and fear responses of growing broilers supplemented with prebiotic or probiotic. Intl. J. Poult. Sci. 7 : 678-685.

Gibson, G.R., and M.B. Roberfroid. 1995. Dietary modulation of the human colonic microbiota: introducing the concept of prebiotics. J. Nutr. 125: 1401-1412.

Hajati, H., and M. Rezaei. 2010. The application of prebiotics in poultry production. Int. J. Poult. Sci. 9: 298-304.

Harvey, J.W. 2012. Veterinary Hematology: A Diagnostic Guide and Color Atlas. Elsevier, Missouri.

Hasan, B., R. Faruque, M. Drobni, J. Waldenstrom, A. Sadique, K. U. Ahmed, Z. Islam, M. B. H. Parvez, B. Olsen, and M. Alam. 2011. High prevalence of antibiotic resistance in pathogenic Escherichia Coli from large- and small-scale poultry farms in bangladesh. Avian Diseases. 55: 689-692.

Houshmand, M., K. Azhar, I. Zulkifli, M.H. Bejo, and A. Kamyab. 2012. Effects of prebiotic, protein level, and stocking density on performance, immunity, and stress indicators of broilers. Poult. Sci. 91: 393401.

Jin, L.Z., Y.W. Ho, N. Abdullah, and S. Jalaludin.
1998. Growth performance, intestinal microbial populations, and serum cholesterol of broilers fed diets containing lactobacillus cultures. Poult. Sci. 77:12591265.

Kaper, J.B., J.P. Nataro, and H.L.T. Mobley. 2004. Pathogenic Escherichia coli. Nature Rev.2: 123-140.

Khuwijitjaru, P., K. Watsanit, and S. Adachi. 2012. Carbohydrate content and composition of product from subcritical water treatment of coconut meal. J. Industr. Eng. Chem. 18: 225-229.

Kim, G.B., Y.M. Seo, C.H. Kim, and I.K. Paik. 2011. Effect of dietary prebiotic supplementation on the performance, intestinal microflora, and immune response of broilers. Poult. Sci. 90: 75-82.

Konca, Y., F. Kirkpinar, S. Mert, and B. Kayhan. 2009. Performance, intestinal microflora, and blood constituents in finishing turkeys fed diets supplemented with dietary mannan oligosaccharide and live yeast. J. Anim. Feed. Sci. 18: 508-517.

Lam, K.M. 1998. Alteration of chicken heterophil and macrophage functions by the infectious bursal disease virus. Microbial Pathogen. 25:147-155.

Lan, P.T., M. Sakamoto, and Y. Benno. 2004. Effects of two probiotic Lactobacillus strains on jejunal and cecal microbiota of broiler chicken under acute heat stress condition as revealed by molecular analysis of $16 \mathrm{~S}$ rRNA genes. Microbiol. Immunol. 48: 917-929.

Leeson, S, and J.D. Summers. 2005. Commercial Poultry Nutrition. 3th edition. Nottingham University Press, Ontario.

Maczulak, A.E., M.J. Wolin, and T.L. Miller.1993. Amounts of viable anaerobes, methanogens and bacterial fermentation products in faeces of rats fed high fiber or fiber-free diets. Appl. and Environ. Microbiol. 59:657-662.

Mirelmann, D., G. Altman, and Y. Eshdat. 1980. Screening of bacterial isolates for mannosespecific lectin activity by agglutination of yeast. J. Clin. Microbiol. 11:328-331.

Moreira, L.R.S., and E.X.F. Filho. 2008. An overview of mannan structure and mannandegrading enzyme systems. Appl. Microbiol. Biotechnol. 79:165-178.

Novak, M., and V. Vetvicka. 2008. B-glucans, history and the present: immunomodulatory 
aspects and mechanisms of action. J. Immunotox. 5: 45-57.

Patterson, J.A., and K. M. Burkholder. 2003. Application of prebiotics and probiotics in poultry production. Poult. Sci. 82:627-631.

Pollack, C., J.W. Carpenter, and N. Antinoff. 2005. In: Birds, 3rd Ed. J Carpenter ed. Exotic Animal Formulary. Elsevier Saunders, St. Louis, MO.

Ramotar, K., J.M. Conly, H. Chubb, and T.J. Louie. 1984. Production of menaquinones by intestinal anaerobes. J. Infect. Dis. 150: 213-218.

Schley, P.D., and C. J. Field. 2002. The immuneenhancing effects of dietary fibres and prebiotics. British J. Nutr. 87: 221-230.

Sirvydis, V., R. Bobiniene, D. Gudaviciute, R. Cepuliene, V. Semaska, D. Vencius, and I. Kepaliene. 2006. Influence of a prebiotic feed additive on some biochemical indices of blood and intestinal microbiota of broiler chickens. Zemes Ukio Mokslai. 4:57-62.

Sohail, M.U., A. Ijaz, M.S. Yousaf, K. Ashraf, H. Zaneb, M. Aleem, and H. Rehman. 2010. Alleviation of cyclic heat stress in broilers by dietary supplementation of mannanoligosaccharide and Lactobacillus-based probiotic: Dynamics of cortisol, thyroid hormones, cholesterol, C-reactive protein, and humoral immunity. Poult. Sci. 89:19341938.

Spring, P., C. Wenk, K. A. Dawson, and K. E. Newman. 2000. The effects of dietary mannanoligosaccharides on cecal parameters and the concentrations of enteric bacteria in the ceca of Salmonellachallenged broiler chicks. Poult. Sci. 79: 205-211.

Tamzil, M.H., R.R. Noor, P.S. Hardjosworo, W. Manalu, and C. Sumantri. 2014. Hematological response of chickens with differens heat shock protein 70 genotypes to acute heat stress. Int. J. Poult. Sci. 13:14-20.

Van den Bogaard, A.E., N. London, C. Driessen, and E.E. Stobberingh. 2001. Antibiotic resistance of faecal Escherichia coli in poultry, poultry farmers and poultry slaughterers. J. Antimicrobiol. Chem. 47: 763-771.

Zinkl, J.G. 1986. Avian hematology. In: Jain NC, editor. Schalm's Veterinary Hematology. 4th Ed. Lea and Fibiger, Philadelphia. p:256273. 